\title{
In illa terra, ubi nullus antiquitatum unquam scriptor fuerit. Historia jako składnik tożsamości ludu cywilizowanego (na przykładzie opowieści Mnicha Teodoryka o okolicznościach chrztu Olafa Świętego)
}

\begin{abstract}
Wstęp
Wiek XII to czas nie tylko narodzin dziejopisarstwa skandynawskiego, ale również jego szybkiego rozkwitu. Wówczas bowiem pojawiła się w Danii, Norwegii i na Islandii spora liczba dzieł historiograficznych. Ich autorzy stawiali sobie za cel utrwalenie na piśmie miejscowych tradycji historycznych. Działali w przekonaniu, że żaden lud nie może uchodzić za cywilizowany, jeżeli nie jest w stanie wylegitymować się udokumentowaną historią. Zadanie, jakie przed sobą stawiali, nie było łatwe. W pierwszej kolejności chodziło o to, by zrekonstruować wydarzenia z odległej przeszłości, w dalszej zaś — by pokazać, że stanowią one integralny element uniwersalnej historii zbawienia, że rozegrały się wedle tej samej co ona matrycy ${ }^{1}$.

Interesujący przykład strategii dowartościowywania dziejów rodzimych w relacji do historii powszechnej stanowić może stworzona przez Mnicha Teodoryka opowieść o okolicznościach chrztu Olafa Świętego ${ }^{2}$. Kronikarz oznajmia w niej, że nie wiadomo, gdzie i kiedy norweski król-męczennik został ochrzczony. W niniejszym artykule zamierzam sprawdzić, czemu służyć ma zestawienie

\footnotetext{
${ }^{1}$ Zob. np. G.W. Weber, Intellegere historiam. Typological Perspectives of Nordic Prehistory — in Snorri, Saxo, Widukind and others, w: Tradition og historieskriving. Kilderne til Nordens aeldste historie, red. K. Hastrup, P. Meulengracht-Sørensen, Århus 1987, s. 95-141; L. Słupecki, Hektor na Islandii. Historia trojańska w źródłach staroislandzkich, czyli o tym, jak Snorri Sturluson włączyt Skandynawów do antycznego dziedzictwa, „Studia Europaea Gnesnensia”, 6 (2012), s. 361-388.

2 Korzystam z edycji: Theodrici Monachi Historia de antiquitate regum Norwagiensium, wyd. G. Storm, Monumenta Historica Norvegiæ. Latinske kildeskrifter til Norges historie i middelalderen udgivne efter offentlig foranstaltning, Kristiania 1880, s. 1-68 [dalej: Mnich Teodoryk]. O Teodoryku, zob. G. Storm, Indledning, w: tamże, s. I-XIV; A.O. Johnsen, Om Theodoricus og hans ,"Historia de antiquitate regum Norwagiensium”, Oslo 1939; J.S.Th. Hanssen, Observations on Theodoricus Monachus and his History of the Old Norwegian Kings, from the End of the XII. sec., „Symbolae Osloenses”, 24, 1945, s. 164-180; tenże, Theodoricus Monachus and European Literature, „Symbolae Osloenses”, 27, 1949, s. 70-127; G. Lange, Die Anfänge der isländisch-norwegischen Geschichtsschreibung, Reykjavík 1989; S. Bagge, Theodoricus Monachus Clerical Historiography in Twelfth-Century Norway, ,Scandinavian Journal of History”, 14, 1989, nr 2, s. 113-133; tenże, Theodoricus Monachus: The Kingdom of Norway and the History of Salvation, w: Historical Narratives and Christian Identity on a European Periphery, red. I.H. Garipzanov, Leiden-Boston 2011, s. 71-90; P. Foote, Introduction, w: Theodoricus Monachus, An Account of the Ancient History of the Norwegian Kings, ttum. D. McDougall, I. McDougall, London 1998, s. VII-XXXI. Nową edycję kroniki od kilkunastu lat przygotowuje norweski filolog klasyczny Egil Kraggerud, <http://egil. kraggerud.no> [dostęp: 21.10.2013].
} 
obok siebie trzech różnych wersji tego wydarzenia, a także — jaką rolę w opowieści pełni odwołanie do historiograficznych niejasności związanych z konwersją Konstantyna Wielkiego. Posługując się materiałem porównawczym, postaram się wskazać na ideologiczny kontekst omawianego przekazu.

Na początek jednak kilka zdań o analizowanym źródle. Historia de antiquitate regum Norwagiensium Mnicha Teodoryka to jedna z trzech XII-wiecznych norweskich kronik-synoptyków, a być może również - najstarsza spośród nich ${ }^{3}$. Wszystko co wiemy o jej autorze, mieści się w sferze domysłów; praktycznie jedynym źródłem informacji na ten temat jest tekst jego kroniki. Z całą pewnością był on Norwegiem $^{4}$, a prawdopodobnie - mnichem benedyktyńskim w Niðaróss albo w Bergen ${ }^{5}$. Zdaniem L. Daae i A.O. Johnsena, kronikarza można utożsamiać z jednym z dwóch norweskich biskupów o tym samym imieniu. Dodajmy, że imiona obydwu hierarchów zostały zapisane w nekrologu augustiańskiego opactwa św. Wiktora w Paryżu (Teodoryk biskup Hamar zmarły w 1196 r. występuje tam jako „noster canonicus”, natomiast Teodoryk arcybikup Niðaróss zmarły w 1214 r. — jako „frater noster"). O ile identyfikacja ta okazałaby się trafna, rzucałaby ona być może pewne światło na wykształcenie naszego kronikarza. Zdaniem Johnsena bowiem, z większością cytowanych przez siebie źródeł pisanych, Teodoryk mógł się zapoznać właśnie w bibliotece paryskiej ${ }^{6}$.

Dzieło Mnicha Teodoryka, znane z pięciu XVII-wiecznych rękopisów ${ }^{7}$, zostało dedykowane Eysteinnowi Erlendssonowi, arcybiskupowi Niðaróss w latach 1161-1188. Datę powstania kroniki można ustalić dość, jak na realia pełnego średniowiecza, precyzyjnie. Zasadnicza narracja urywa się w niej na $\mathrm{r}$. 1130, jednak Teodoryk, wspominając w jednym z ostatnich rozdziałów o śmierci Nikulása Sigurðarssona w Niðaróss we wrześniu 1176 r., określa jego zabójcę, Eysteinna meyla mianem ,infelix tyrannus”, z czego wynika, że ów pretendent do tronu norweskiego w chwili pisania już nie żył. Jako terminus post quem przyjmuje się zatem w literaturze przedmiotu śmierć Eysteinna w styczniu 1177 r. po bitwie pod Ré ${ }^{8}$. Nieprzekraczalnym terminus ante quem wydaje się z kolei śmierć arcybiskupa Eysteinna w stycz1188 roku?

\footnotetext{
${ }^{3}$ O najdawniejszym dziejopisarstwie islandzko-norweskim, zob. B. Aðalbjarnarson, Om de norske kongers sagaer, Oslo 1937; S. Beyschlag, Konungasögur. Untersuchungen zur Königssaga bis Snorri. Die älteren Übersichtswerke samt „,Ynglingasaga”, Kopenhagen 1950; S. Ellehøj, Studier over den celdste norrøne historieskrivning, København 1965; Th.M. Andersson, Kings' Sagas (Konungasögur), w: Old Norse-Icelandic Literature. A Critical Guide, red. C.J. Clover, J. Lindow, New York 1985, s. 197-238; T. Ulset, Det genetiske forholdet mellom „Ágrip”, „Historia Norwegice” og „Historia de antiquitate regum Norwagiensium”. En analyse med utgangpunkt i oversettelsesteknikk samt en diskusjon omkring begrepet „,latinisme" $i$ samband med norrøne tekster, Oslo 1983; G. Lange, Die Anfänge, passim; N. Kersken, Geschichtsschreibung im Europa der „,nationes”. Nationalgeschichte Gesamtdarstellungen im Mittelalter, Köln [etc.] 1995, s. 399-483; Sh. Ghosh, Kings' Sagas and Norwegian History. Problems and Perspectives, Leiden-Boston 2011.

${ }^{4}$ Zob. G. Lange, Die Anfänge, s. 19; P. Foote, Introduction, s. IX.

5 Zob. S. Bagge, Theodoricus Monachus - Clerical, s. 115, przyp. 9; P. Foote, Introduction, s. IX n.

${ }^{6}$ L. Daae, Om Historieskriveren 'Theodoricus monachus' og om Biskop Thore af Hamar, „Historisk Tidsskrift”, 3, 1895, s. 397-411; A.O. Johnsen, Om Theodoricus og hans, s. 90 n. Ponadto - S. Bagge, Nordic Students at Foreign Universities until 1660, „Scandinavian Journal of History”, 9, 1984, nr 1, s. 3; tenże, Theodoricus Monachus: The Kingdom, s. 71 n.; L.B. Mortensen, The Anchin manuscript of „Passio Olavi” (Douai 295), William of Jumièges, and Theodoricus Monachus: New evidence for intellectual relations between Norway and France in the 12th century, ,Symbolae Osloenses”, 75, 2000, nr 1, s. 165-189. Por. jednak J.S.Th. Hanssen, Observations on Theodoricus Monachus, s. 166 n.; tenże, Theodoricus Monachus, s. 122 n.; P. Foote, Introduction, s. X.

${ }^{7}$ Wywodzą się one od zaginionego obecnie kodeksu, o którego losach aż do ok. 1620 r. nie wiemy nic pewnego. Być może został spisany w jakimś skandynawskim skryptorium w XIII w., w połowie XV należał do legata papieskiego Marinusa de Fregeno, z którego rąk trafił do biblioteki senatu lubeckiego, gdzie został odnaleziony przez Johanna Kirchmanna. Zob. M.Cl. Gertz, Fortale, w: Scriptores Minores Historice Danicae Medii AEvi, t. 2, København 1918-1920, s. 444-456; P. Lehmann, Auf der Suche nach alten Texten in nordischen Bibliotheken, w: tenże, Erforschung des Mittelalters. Ausgewählte Abhandlungen und Aufsätze, t. 1, Stuttgart 1959, s. 286-291; tenże, Skandinaviens Anteil an der lateinischen Literatur und Wissenschaft des Mittelalters, t. 2, München 1937, s. 120-122; G. Lange, Die Anfänge der, s. 13-18; P. Foote, Introduction, s. XXX-XXXI; K. Skovgaard-Petersen, Et håndskriftfund i Lübeck ca. 1620. Om den spinkle overlevering af to norske nationalklenodier, „Fund og Forskning”, 41, 2002, s. 107-127.

${ }^{8}$ Mnich Teodoryk, c. 31, s. 63. W sferze prawdopodobieństwa pozostaje wszakże możliwość, że wcześniejsze partie kroniki mogły powstać jeszcze przed tą datą.

9 Zob. G. Storm, Indledning, s. VIII; A.O. Johnsen, Om Theodoricus og hans, s. 84 n.; J.S.Th. Hanssen, Theodoricus Monachus, s. 123 n.; S. Bagge, Theodoricus Monachus - Clerical, s. 114; P. Foote, Introduction, s. XI-XIII.
} 
Teodoryk kilkakrotnie przedstawia się jako pierwszy kronikarz spisujący dzieje swojego kraju, z czego historycy zwykli wyciągać wniosek (inna sprawa, na ile słuszny), że nie dysponował on żadnym źródłem pisanym dotyczącym historii Norwegii ${ }^{10}$. W rzeczywistości, poza islandzkimi antiquis carminibus, pod którymi kryją się zapewne poematy skaldów, kronikarz znał również Íslendingabók Ariego Mądrego i trudny do identyfikacji Catalogus regum Norwagiensium, a także jakiś zbiór cudów św. Olafa ${ }^{11}$. Na jego erudycję składają się ponadto Biblia, autorzy starożytni (w tym prawdopodobnie Kalcydiusz i Makrobiusz ${ }^{12}$ ) i chrześcijańscy (Hieronim, Izydor, Augustyn), ponadto klasycy historiografii wczesnośredniowiecznej (Jordanes, Beda, Paweł Diakon, Einhard), a także Ryszard od św. Wiktora, Siegebert z Gembloux i Wilhelm z Jumièges.

Historia de antiquitate regum Norwagiensium składa się z 34 rozdziałów, jest dziełem ukończonym i wykazującym przemyślaną strukturę. Widać to choćby po ramach chronologicznych kroniki. Narracja rozpoczyna się od objęcia tronu norweskiego przez Haralda Pięknowłosego. Wybór takiej cezury umotywowany został brakiem źródeł pisanych dotyczących okresu wcześniejszego, jak również tym, że to od Haralda rozpoczyna się dynastia królewska w Norwegii ${ }^{13}$. Z drugiej strony, narracja kroniki została świadomie urwana na r. 1130, kiedy to zmarł Sigurd Jórsalafari. Teodoryk wyjaśnia, że lepiej nie relacjonować różnego rodzaju bezeceństw, do jakich doszło w ciągu półwiecza wojen domowych, które minęło od tego czasu ${ }^{14}$. Na treść kroniki składa się zatem wykład dziejów władców Norwegii od połowy IX w. do r. 1130, ze szczególnym uwzględnieniem dwóch królów-chrystianizatorów: Olafa Tryggvasona i Olafa Świętego.

Wywód został kilkanaście razy przerwany dygresjami, dotyczącymi dziejów powszechnych, głównie starożytnych, i niekoniecznie pozostającymi w bezpośrednim związku z głównym wątkiem. Nie sposób dać wiary Teodorykowi, kiedy zapewnia, że pełnią one funkcję li-tylko ornamentu literackiego czy popisu erudycji ${ }^{15}$. Ich rola polega raczej na powiązaniu historii Norwegii z wydarzeniami $\mathrm{z}$ historii powszechnej i nadaniu jej w ten sposób głębszego sensu ${ }^{16}$.

\section{Okoliczności chrztu Olafa Świętego}

Powróćmy teraz do wspomnianej już opowieści z rozdziału 13 kroniki, zatytułowanego „Opinio quorundam de baptismo beati Olavi”. Pojawia się ona w kontekście misjonarskiej działalności Olafa Tryggvasona ${ }^{17}$. Władca ten, mówi kronikarz, ,aby łatwiej cały kraj Chrystusowi podporządkować, trzy swoje siostry wydał za mąż za wodzów, jedną o imieniu Astrid za Erlinga syna Skjalga, drugą za

\footnotetext{
${ }_{10}$ Tak uważali m.in.: G. Storm, Indledning, s. X n.; B. Aðalbjarnarson, Om de norske kongers sagaer, s. 6, 49-54; S. Beyschlag, Konungasögur. Untersuchungen, s. 122-128; S. Ellehøj, Studier over den celdste, s. 177 n., 297; L.B. Mortensen, rec.: Theodoricus Monachus, An Account of the - „Maal og Minne”, 2000, s. 101-104. Ponadto zestawienie literatury w: G. Lange, Die Anfänge der, s. 211, przyp. 276-277; S. Bagge, The Making of a Missionary King: The Medieval Accounts of Olaf Tryggvason and the Conversion of Norway, ,Journal of English and Germanic Philology”, 105, 2006, nr 4, s. 485, przyp. 52. ${ }^{11}$ Na temat wernakularnych źródeł Teodoryka, zob. G. Lange, Die Anfänge, s. 98-120; P. Foote, Introduction, s. XV-XVIII.

12 Zob. T. Frank, Some Classical Quotations from the Middle Ages, „Classical Philology”, 4, 1909, z. 1, s. 83;. F. Paasche, Über Rom und das Nachleben der Antike im norwegischen und isländischen Schrifttum des Hochmittelalters, ,Symbolae Osloenses", 13, 1934, s. 137 n.; A.O. Johnsen, Om Theodoricus og hans, s. 32, 56.

${ }_{13}$ Mnich Teodoryk, prolog, s. 3-4; c. 1, s. 6. Zob. S. Bagge, Theodoricus Monachus: The Kingdom, s. 74 n. W sprawie daty objęcia tronu przez Haralda, zob. V. Skånland, The Year of King Harald Fairhair's Access to the Throne according to Theodoricus Monachus', „Symbolae Osloenses”, 41, 1966, s. 125-128; G. Lange, Die Anfänge, s. 115-118; E. Kraggerud, Theodoricus Scrutinized, „Collegium Medievale”, 11, 1998, s. 123.

${ }_{14}$ Mnich Teodoryk, c. 34, s. 67. Zob. H.J. Orning, Unpredictability and Presence. Norwegian Kingship in the High Middle Ages, Leiden-Boston 2008, s. 331, przyp. 53; Sh. Ghosh, Kings' Sagas and Norwegian, s. 188 n.; B. Bandlien, Hegemonic Memory, Counter-Memory, and Struggles for Royal Power. The Rhetoric of the Past in the Age of King Sverrir Sigurðsson of Norway, „Scandinavian Studies”, 85, 2013, z. 3, s. 355-377.

${ }_{15}$ Mnich Teodoryk, prolog, s. 4: „Digressiones etiam [...] ad delectandum animum lectoris [...] adjunximus”.

16 O dygresjach w dziele Teodoryka, zob. J.S.Th. Hanssen, Theodoricus Monachus, s. 78-124; S. Bagge, Theodoricus Monachus - Clerical, s. 116-123; tenże, Theodoricus Monachus: The Kingdom, s. 74 n.; P. Foote, Introduction, s. XXV n.

${ }_{17}$ Por. S. Bagge, Theodoricus Monachus: The Kingdom, s. 77 n.
} 
Porgeira potężnego męża z Wic, który później spalił Goðroða syna Gunnhildy w pewnym domu za to, że ów pragnął najechać królestwo przeciw Olafowi, trzecią za Hyrninga, brata tegoż. Gdy wszystkich ochrzcił, skierował się na wyżyny, czyli do Upplandu, gdzie trzyletni chłopiec Olaf, który później stał się pobożnym męczennikiem Chrystusa, znalazł się wówczas wraz z matką Astą, po śmierci ojca Haralda (był on synem Goðroða syra, którego ojcem był Berno, którego nazywano Kupcem i który był synem Haralda Pięknowłosego). Ten Olaf był radosną nadzieją i przyszłą ozdobą Norwegów. Wtedy i jego wraz z matką wedle niektórych ochrzcił tam; inni zapewniają, że w Anglii przyjął chrzest; lecz ja czytałem w Historii Normanów [Wilhelma z Jumièges], iż w Normandii przez Roberta metropolitę Rouen został ochrzczony. Pewnym jest, że Wilhelm książę Normandii wezwał go na pomoc przeciwko Robertowi królowi Francji, zwanemu Kapet (był on synem Hugona Kapeta, najszlachetniejszego władcy), który księciu Wilhelmowi planował wypowiedzieć wojnę wraz z hrabią Flandrii. Zmierzał zaś do tego, by wypędzić go z Normandii, którą to prowincję jego przodkowie siłą odebrali królowi Franków. Lecz niezależnie od tego, czy w Rouen czy w Anglii został ochrzczony, pewnym tedy jest, że był w dojrzałym wieku, gdy ukoronowany został męczeństwem, jak mówią ci, którym najbardziej w tej kwestii należy wierzyć. Nic dziwnego, że przydarzyło się to z Olafem w tym kraju, w którym nigdy nie było żadnego kronikarza dziejów starożytnych, skoro to samo napisał błogosławiony Hieronim o Konstantynie Wielkim, synu Konstancjusza i Heleny, że jedni mówią, iż w Bitynii został ochrzczony w późnej starości, inni, że w Konstantynopolu, jeszcze inni — w Rzymie przez błogosławionego papieża Sylwestra, i któż prawdziwiej napisał, że wciąż toczy się spór nierozstrzygnięty”"18.

Ogólne wrażenie z lektury cytowanego fragmentu kroniki jest następujące: Teodoryk zestawia ze sobą różne wersje wydarzeń, nie rozstrzygając, która z nich jest zgodna z prawdą; et adhuc sub judice lis est, puentuje, cytując Ars poetica Horacego. Tego typu działanie to oczywiście standardowy element w warsztacie średniowiecznego dziejopisarza - jak zauważa Krzysztof Pomian, ,gdy miano do czynienia z dwoma autorytetami uważanymi za równorzędne, przytaczano po prostu dostarczane przez nie informacje, nawet jeśli nie były one ze sobą zgodne; drugą z tych informacji poprzedzało zazwyczaj jakieś zdanie konstatujące tę rozbieżność, np. alii vero affirmant lub sed alii dicunt"19. $\mathrm{Z}$ taką metodą spotykamy się zresztą jeszcze parokrotnie w tekście samej kroniki ${ }^{20}$.

\footnotetext{
18 Mnich Teodoryk, c. 13, s. 21-23: „Rex ergo Olauus ut facilius totam Christo subjugaret regionem, tres sorores suas principibus conjunxit viris, unam Erlingi filio Scialgs, Astritham nomine, alteram Porgeiri potenti viro de Wic, qui postea concremavit Goðroð in quadam domo filium Gunnhildar, cum ille vellet invadere regnum contra Olavum, tertiam Hyrningi fratri eiusdem. Cumque omnes baptizari fecisset, cursum tetendit ad superiora, scilicet Uplond. Ibique tunc puerulum Olavum trium annorum, qui postea devotus Christi martyr factus est, invenit cum matre Asta, patre iam defuncto Haraldo: [Hic fuit filius Goðrotðar syr, cui extitit pater Bernhardo, qui cognominatus est Mercator et fuit filius Haraldi Bene-comati] felicem spem et decus Norwagiensium futurum. Tunc et eum una cum matre ibidem secundum quosdam baptizari fecit; alii contendunt eum in Anglia baptizatum; sed et ego legi in Historia Normannorum, quod a Roberto in Normandia Rothomagensi Metropolitano baptizatus fuerit. Constat enim, quod Wilhelmus Dux Normanniæ adscriverit eum sibi in auxilium contra Robertum Regem Franciæ cognomento Capet (qui fuit filius Hugonis Capet nobilissimi Ducis), qui Duci Wilhelmo una cum Comite Flandrensi bellum inferre parabant. Nitebatur enim eum expellere a Normannia, eo quod Antecessores ejus vi extorserant provinciam a Rege Francorum. Sed sive Rothomagi sive in Anglia baptizatus fuerit, tunc constat eum fuisse provectioris ætatis, quando martyrio coronatus est, quomodo illi dicunt, quibus maxime in hujusmodi credendum est. Nec mirum de Olavo hoc contigisse in illa terra, ubi nullus antiquitatum unquam scriptor fuerit, cum idem scribat beatus Hieronymus de Constantino Magno filio Constantii et Helenæ, quod quidam dicant eum Bithyniæ baptizatum fuisse in ultima senectute, alii Constantinopoli, quidam Romæ a beato Sylvestro papa, et adhuc sub judice lis est quis verius scripserit". Tekst edycji w kilku miejscach emendowałem za: Berlin Staatsbibliothek, sygn. Ms. lat. fol. 356, k. 16v-18r (skan kopii L online: <http://digital-beta.staatsbibliothek-berlin.de/werkansicht/?PPN=PPN640614841\&PHYSID=PHYS_0001> [dostęp: 27.11.2013]). Tłumaczenia źródeł, o ile nie podano inaczej, pochodzą ode mnie. W tym wypadku, puenta wykładu (adhuc sub judice lis est) stanowi cytat z Horacego (Ars Poetica, wers 78), którego przekład podaję niemal dosłownie za Stefanem Gołębiowskim - Horacy, Dzieła, Warszawa 1986, s. 222; por. J.S.Th. Hanssen, Theodoricus Monachus, s. 83.

${ }^{19}$ K. Pomian, Przeszłość jako przedmiot wiary. Historia i filozofia w myśli średniowiecza, wyd. 2, Warszawa 2009, s. 94 n. Również - M. Schulz, Die Lehre von der historischen Methode bei den Geschichtsschreibern des Mittelalters (VI.-XIII. Jahrhundert), Berlin-Leipzig 1909, s. 45-50; P. Żmudzki, Nowe wersje opowieści Galla Anonima w dziele Wincentego Kadtubka (bitwa Chrobrego z Rusinami, Czesi oszukujacy Szczodrego, dzieciństwo Kazimierza Odnowiciela), w: Onus Athlanteum. Studia nad Kronika biskupa Wincentego, red. A. Dąbrówka, W. Wojtowicz, Warszawa 2009, s. 320 n. ${ }^{20}$ Zestawienie wzmianek w: J.S.Th. Hanssen, Theodoricus Monachus, s. 121; P. Foote, Introduction, s. XXIV.
} 
Rzecz w tym, że konfrontacja trzech różnych wersji dotyczących konwersji Olafa ${ }^{21}$ i Konstantyna prowadzi w tym wypadku do stworzenia dość wyrafinowanej konstrukcji intelektualnej. Stan wiedzy na temat obydwu władców jest podobny (nie sposób jednoznacznie rozstrzygnąć, kiedy i gdzie zostali ochrzczeni), a wydaje się, że i oni sami są w jakiś sposób do siebie podobni. Wynika z tego — sugeruje Teodoryk — że dzieje Norwegii są godne zestawienia z wielką historią powszechną. W dalszym wywodzie skupię się na dwóch ostatnich zdaniach opowieści, są one bowiem najbardziej bogate w treść i wywołały najwięcej kontrowersji w literaturze przedmiotu. Moje rozważania będą miały zatem (w dużej mierze) charakter polemiki z dotychczasowymi ustaleniami.

\section{Autorytet Hieronima}

Zacznijmy od źródeł, z jakich Teodoryk mógł czerpać wiedzę o Konstantynie Wielkim. Pisząc o wątpliwościach związanych ze chrztem pierwszego chrześcijańskiego cesarza, kronikarz powołuje się na autorytet św. Hieronima. Tymczasem ten stwierdza, że „Konstantyn u kresu swego życia ochrzczony przez Euzebiusza biskupa Nikomedii, zwrócił się ku ariańskiej herezji”22. Jak widać, przekaz jest jednoznaczny, nie ma tu śladu po trzech różnych wersjach chrztu cesarza, jest tylko jedna: rzecz miała miejsce w Bitynii i dokonała się przy udziale biskupa Euzebiusza. Teodoryk tymczasem nie pozostawia najmniejszych wątpliwości, że — jego zdaniem — wszystkie możliwe opinie dotyczące chrztu Konstantyna, jakie podał, zostały zarejestrowane właśnie przez Hieronima. Przypomnijmy odpowiedni fragment Historia de antiquitate: „cum idem scribat beatus Hieronymus de Constantino Magno filio Constantii et Helenæ, quod quidam dicant eum Bithyniæ baptizatum fuisse in ultima senectute, alii Constantinopoli, quidam Romæ a beato Sylvestro papa". Teoretycznie, możliwe byłoby odczytanie tego passusu w taki sposób, że jedynie pierwsza wersja (zgodna z tekstem jego kroniki) przypisana została Hieronimowi, dwie pozostałe natomiast jakimś alii i quidam. Nie pozwala na to wszakże konstrukcja gramatyczna zdania, z której jasno wynika, że całość jest cytatem z tegoż doktora Kościoła, a nie konfrontacją cytatu z innymi źródłami.

Możliwe, że Teodoryk korzystał z innego źródła, a mianowicie z listu papieża Aleksandra III skierowanego do arcybiskupa Niðaróss, Eysteinna Erlendssona. List ten, pozbawiony datacji, został zdaniem Walthera Holtzmanna, wysłany pomiędzy 1164 a 1181 r. Ostatnio datuje się go jednak na lata 1161-1172, a więc chyba wcześniej niż swoją kronikę zaczął pisać Teodoryk. List zawiera odpowiedzi

\footnotetext{
${ }^{21}$ Krótko tylko zaznaczmy, że kronikarz cytuje Gesta Normannorum ducum Wilhelma z Jumièges z niezgodzie z faktami historycznymi, myląc pojawiające się w tym źródle postacie (np. Wilhelm Długi Miecz zamiast Ryszarda II — The Gesta Normannorum Ducum of William of Jumièges, Orderic Vitalis and Robert of Torigni, wyd. E.M.C. van Houts, t. 2, Oxford 1995, lib. V, c. 12, s. 24 n.). Uwagę badaczy przykuwała zbieżność tekstu Teodoryka z informacją zawartą w datowanej przeważnie na lata 70. XII wieku Passio Olavi: władca-męczennik otóż euangelice ueritatis sinceritate in Anglia comperta, fidem toto admisit pectore, et ad baptismi gratiam in urbe Rotomagi deuota animi alacritate conuolauit (Passio et Miracula Beati Olaui, wyd. F. Metcalfe, Oxford 1881, c. 1, s. 68). A zatem hagiograf (w którym widziano niekiedy arcybiskupa Eysteinna) lokuje chrzest Olafa w Rouen, wspomina również o Anglii, jednak nie w kontekście lokalizacji chrztu, która jest u niego całkowicie jednoznaczna. Stąd Teodorykowe sed et ego legi in Historia Normannorum, quod a Roberto in Normandia Rothomagensi Metropolitano baptizatus fuerit odczytywano niekiedy jako nawiązanie do Pasji właśnie, nie dawano bowiem wiary, by kronikarz mógł zdobyć informację o chrzcie Olafa w Rouen niezależnie i na dodatek ją podważać (zob. np. E. Skard, Merknader til Passio Olavi, „Historisk tidsskrift”, 29, 1930-1933, s. 369; A.O. Johnsen, Om Theodoricus og hans, s. 21; S. Ellehøj, Studier over den celdste, s. 181; E. Gunnes, Erkebiskop Eystein. Statsman og kirkebygger, Oslo 1996, s. 216; P.A. White, The Latin Men: The Norman Sources of the Scandinavian Kings' Sagas, „Journal of English and Germanic Philology”, 98, 1999, nr 2, s. 163 n.). W rzeczywistości fraza ta jest zreferowaniem opinii alternatywnej względem tego, co na temat chrztu Olafa „alii contendunt”, a nie dyskusją ze świadectwem Passio Olavi. W rezultacie, zbieżność z tym tekstem nie ma znaczenia dla zrozumienia sensu analizowanej opowieści - por. D. McDougall, I. McDougall, w: Theodoricus Monachus, An Account, s. 71 n., przyp. 100-102; L.B. Mortensen, The Anchin manuscript, passim; S. Bagge, The Making of a Missionary King, s. 491, przyp. 68.

${ }^{22}$ Eusebii Pamphili Chronicorum liber secundus, s. Hieronymo interpreté et ampliatore, wyd. J.-P. Migne, PL, t. 27, Parisiis 1866, s.a. 341, kol. 499-500: „Constantinus extremo vitæ suæ tempore ab Eusebio Nicomediensi episcopo baptizatus, in Arianum dogma declinat".
} 
na pytania Eysteinna, dotyczące m.in. małżeństw chrześcijańskich, kwestii liturgicznych, etc. Czytamy tam m.in.: „Wierzymy zaś, że Konstantyn został ochrzczony nie przez Euzebiusza, tylko przez świętego Sylwestra"23.

Nawet jeśli Teodoryk znał list papieża (co mieści się w granicach prawdopodobieństwa - list i kronika pochodzą z tego samego okresu i skierowane zostały do tego samego odbiorcy), to jedynie zaczerpnął z niego informacje, diametralnie zmienił natomiast kontekst, w jakim zostały one podane. O ile Aleksander jednoznacznie rozstrzyga kwestię okoliczności chrztu Konstantyna na korzyść tezy „rzymskiej”, to Teodoryk zestawia na równych prawach trzy różne opinie w tej sprawie. Czyni tak dlatego, że zależy mu na tym, by zachodziła symetria między sytuacją Olafa a sytuacją Konstantyna $^{24}$ - możliwe nawet, że wykreował on nieznaną skądinąd informację o chrzcie cesarza w założonym przez niego mieście nad Bosforem ${ }^{25}$ po to, by analogia ta zgadzała się również pod względem liczbowym, tzn. żeby opinii dotyczących okoliczności chrztu obydwu władców było po trzy. Niezależnie zaś od tego, z jakiego źródła czerpał Teodoryk informacje o Konstantynie, istotne jest to, że swoją konstrukcję dotyczącą chrztu cesarza poparł autorytetem św. Hieronima. I nawet w dziele Hieronima - mówi Teodoryk — zdarzają się takie sytuacje, że nie sposób rozstrzygnąć, ,jak to było naprawdę".

\section{Mnich Teodoryk i XII-wieczna dyskusja nad Donatio Constantini}

Pozostańmy na chwilę przy liście Aleksandra III, pomoże nam to umiejscowić motyw chrztu Konstantyna w klimacie intelektualnym drugiej połowy XII wieku. Papież negując (z pewną dozą ostrożności - zwrot credimus) informację o chrzcie cesarza w Bitynii, opowiada się za tezą „rzymską”. Tradycja wiążąca nawrócenie Konstantyna z osobą Sylwestra sięga V-wiecznego Liber Pontificalis, który mówi również o tym, że władca został cudownie uleczony przez papieża $\mathrm{z}$ trądu ${ }^{26}$. Tradycja ta była na tyle rozpowszechniona w średniowieczu, że Grzegorz z Tours nazywając Chlodwiga „Nowym Konstantynem", przyrównał Remigiusza właśnie do Sylwestra ${ }^{27}$. Jej ślady odnaleźć można również w Skandynawii - by wspomnieć o islandzkiej Silvesters Saga ${ }^{28}$, czy o ołtarzu w kościele katedralnym w Niðaróss, ufundowanym w 1161 r. przez arcybiskupa Eysteinna, a poświęconym Janowi Chrzcicielowi, Wincentemu Męczennikowi i Sylwestrowi ${ }^{29}$.

Kwestia okoliczności chrztu Konstantyna była w XII w. ważkim argumentem w debacie nad autentycznością bądź prawomocnością Donatio Constantini. Nie czując się kompetentny, by referować

\footnotetext{
${ }^{23}$ Alexander III A.[ugustino] Trundensi archiepiscopo, w: W. Holtzmann, Krone und Kirche in Norwegen im 12. Jahrhundert (Englische Analekten III), „Deutsches Archiv für Geschichte des Mittelalters”, 2, 1938, s. 386: „Baptismum autem Constantini non ab Eusebio, set a beato Siluestro credimus celebratum”. W sprawie obecnie przyjmowanej datacji listu D. McDougall, I. McDougall, w: Theodoricus Monachus, An Account of, s. 74, przyp. 106.

${ }^{24}$ Zob. J.S.Th. Hanssen, Theodoricus Monachus, s. 102, 121 n. Hanssen abstrahował informacje o Konstantynie z kontekstu opowieści o Olafie, jednak bodaj jako pierwszy zwrócił uwagę na zbieżność pomiędzy tekstem listu i kroniki. Mnie tymczasem bardziej niż to, skąd Teodoryk czerpał informacje, interesuje to, do czego je wykorzystywał. Podobnie - P. Foote, Introduction, s. XII; S. Bagge, The Making of a Missionary King, s. 491, przyp. 68.

${ }^{25}$ Por. D. McDougall, I. McDougall, w: Theodoricus Monachus, An Account, s. 74, przyp. 106.

${ }^{26}$ Le Liber Pontificalis, wyd. L. Duchesne, t. 1, Paris 1886-1892, s. 170, 174.

${ }_{27}$ Gregorii Episcopi Turonensis Decem Libri Historiarum, wyd. B. Krusch, MGH SrM, t. 1, z. 1, Hannoverae 1951, lib. II, c. 31, s. 77. Na temat chrztu Chlodwiga, zob. np. D. Shanzer, Dating the baptism of Clovis: the bishop of Vienne vs. the bishop of Tours, „Early Medieval Europe”, 7, 1998, s. 29-57; B. Dumézil, Les racines chrétiennes de l'Europe. Conversion et liberté dans les royaumes barbares Ve-VIIle siècle, Paris 2005, s. 152-155, 171 n., 217-223.

28 Silvesters Saga, w: Heilagra Manna Søgur, wyd. C.R. Unger, t. 2, Christiania 1877, s. 245-280.

29 „Altare hoc dedicatum est ab Augustino archiepiscopo anno primo episcopatus eius ad laudem domini nostri Jhesu Christi in honore sancti Johannis baptiste et sancti Vincentii martyris et sancti Silvestri anno ab incarnatione domini millesimo centesimo LXI sexto Kalendas Decembrium" - I. Undset, Indskrifter fra middelalderen i Trondhjems domkirke, Christiania 1888, s. 5, (cyt. za:) E. Vandvik, Donatio Constantini and Early Norwegian Church Policy, „Symbolae Osloenses”, 21, 1954-1956, s. 132. Por. J.S.Th. Hanssen, Theodoricus Monachus, s. 102, 111.
} 
całość owej dyskusji czy jej historyczne tło ${ }^{30}$, odwołam się jedynie do kilku przykładów. Zacznijmy od komentarza do Psalmu LXIV, którego autor, Gerhoh z Reichersberga, zajmował takie samo stanowisko jak papież Aleksander, tyle że wyrażał je z dużo większą stanowczością: „,esarz Konstantyn zaiste został ochrzczony, nie jak heretycy twierdzą, przez heretyckiego Euzebiusza arianina, lecz jak katolicy orzekają, przez katolickiego biskupa miasta Rzymu Sylwestra"31. Nieco dalej opowiada Gerhoh o swojej wizycie w Rzymie i przy tej okazji wspomina, że Konstantyn „został bądź ochrzczony bądź powtórnie ochrzczony w herezji ariańskiej, jak wmawiać się zdaje Historia Tripartita"32.

Podobnie Ekkehard z Aura wspominał, że cesarz Konstantyn ,przez świętego Sylwestra papieża, wraz z matką i wieloma innymi na wiarę został nawrócony i ochrzczony"33 — by chwilę później zastrzec: „Pisali jednak niektórzy, że cesarz Konstantyn w ariańską herezję popadł i przez Euzebiusza biskupa Nikomedii został powtórnie ochrzczony, czego kościelna historia nie naucza" ${ }^{34}$. Zauważmy, że Gerhoh i Ekkehard zajmują takie samo stanowisko jak papież Aleksander, jednak w tekstach ich autorstwa znaleźć można jeszcze jeden element. Mimo że teza „bityńska” zostaje w nich zanegowana na korzyść „rzymskiej”, to - wbrew pozorom — nie jest ona względem niej alternatywna. Falsyfikacji nie jest poddana bowiem informacja o chrzcie w Bitynii w ogóle, ale o chrzcie powtórnym, już w obrządku ariańskim.

Inaczej uważał z kolei Otto z Fryzyngi: „Zatem to, co czytamy w Żywocie św. Sylwestra o trądzie i chrzcie Konstantyna, wydaje się apokryfem. Opowiada jednak Historia Tripartita, że w Nikomedii pod koniec życia został on ochrzczony"35. Pomimo zajęcia przez kronikarza odmiennego stanowiska, znajdujemy tu identyczną strukturę wypowiedzi, opartą na przeciwstawieniu tezy „rzymskiej” i „bityńskiej”. Zauważmy może jeszcze, że zarówno Gerhoh, jak i Otto jako źródła tej drugiej nie podają kroniki Hieronima, tylko Historia Tripartita Kasjodora ${ }^{36}$.

Nie sposób rozstrzygnąć, czy Teodoryk mógł znać którykolwiek z przytoczonych wyżej tekstów. W odróżnieniu od Ottona z Fryzyngi, Gerhoha z Reichersberga czy Ekkeharda z Aura, nie zajmował w dyskusji nad miejscem chrztu Konstantyna jednoznacznego stanowiska, tylko wyciągał z niej własne wnioski. Nie ulega przy tym wątpliwości, że kwestia dokonanej przez cesarza donacji była mu dobrze znana. W dygresji poświęconej podbojowi państwa longobardzkiego przez Karola Wielkiego wywołany został bowiem problem władzy królewskiej nad Italią. Kronikarz wkłada wówczas w usta bezimiennego papieża następującą wypowiedź, skierowaną do Karola: „Ja nie cielesny, lecz duchowy dzierżę miecz; mnie wystarczy, jeśli Kościołowi jego prawo i patronat zostaną oddane, jeśli świętemu

${ }^{30} \mathrm{Z}$ bogatej literatury, zob. np. J.J.I. von Döllinger, Fables respecting the Popes in the Middle Ages, tłum. A. Plummer, New York 1872, s. 88-182; G. Laehr, Die Konstantinische Schenkung in der abendländischen Literatur bis zur Mitte des 14. Jahrhunderts, Berlin 1926 (Historische Studien, 166); W. Levison, Konstantinische Schenkung und Silvester-Legende, w: tenże, Aus rheinischer und fränkischer Frühzeit, Düsseldorf 1948, s. 390-465; G. Antonazzi, Lorenzo Valla e la polemica sulla donazione di Constantino. Con testi inediti dei secoli XV-XVII, Roma 1985, s. 24 n.; G. Fowden, The Last Days of Constantine: Oppositional Versions and Their Influence, „The Journal of Roman Studies”, 84, 1994, s. 153-170; J. Fried, Donation of Constantine and Constitutum Constantini. The Misinterpretation of a Fiction and its Original Meaning. With a contribution by Wolfram Brandes: „,The Satraps of Constantine”, Berlin-New York 2007, s. 11-33; H. Manikowska, Przedmowa, [w:] Lorenzo Valla, O rzekomej, sfatszowanej donacji Konstantyna, tłum. K. Kokosiewicz, Warszawa 2015, s. 26 n.

31 Gerhohi Praepositi Reichersbergensis Commentarius in Psalmum LXIV, wyd. E. Sackur, MGH Libelli de lite imperatorum et pontificum, t. 3, Hannoverae 1897, s. 446: ,baptizato videlicet Constantino imperatore, non ut heretici contendunt, ab heretico Eusebio Arriano, sed ut catholici sentiunt, a catholico urbis Rome pontifice Silvestro".

32 Tamże, s. 447: „vel baptizatus vel rebaptizatus fuisset in heresi Arriana, ut insinuare videtur hystoria Tripartita”.

${ }_{33}$ Ekkehardi Chronicon Universale, wyd. G. Waitz, P. Kilon, MGH SS, t. 6, Hannoverae 1844, s. 112: ,per sanctum Silvestrum papam, una cum matre aliisque multis ad fidem conversus est et baptizatus".

${ }^{34}$ Tamże: Scribunt autem quidam, Constantinum imperatorem in Arrianam heresim incidisse et ab Eusebio Nicomediensi episcopo rebaptizatum fuisse, quod aecclesiastica historia non docet.

${ }_{35}$ Ottonis episcopi Frisingensis Chronica sive Historia de duabus Civitatibus, wyd. A. Hofmeister, MGH SrG in us. schol., Hannoverae et Lipsiae 1912, lib. IV, c. 1, s. 185: „Proinde ea, quae in beati Silvestri Vita de lepra et conversione eius leguntur, apocrifa videntur. Refert tamen Tripertita Hystoria eum in Nicomedia circa finem vitae baptizatum esse".

${ }^{36}$ M.A. Cassiodorus, Historia ecclesiastica, vocata Tripartita, wyd. J.-P. Migne, PL, t. 69, Parisiis 1865, lib. III, c. 12, kol. 956. 
Piotrowi co jego zostanie przywrócone. Do ciebie należy, powiada, najdroższy synu, zdecydować, czy tytuł królewski w Italii winien zostać utrzymany, skoro Konstantyn, syn Heleny, ku czci Pana Naszego Jezusa Chrystusa zrzekł się go i świętemu Piotrowi i rzymskiemu biskupowi w wieczyste prawo przekazał" 37 .

To zapewne najstarsza w literaturze norweskiej wzmianka o Donatio Constantini. Niemniej mamy również inne świadectwa zainteresowania XII-wiecznego Kościoła norweskiego problematyką chrztu Konstantyna, dokonanej przez niego darowizny, czy postaci papieża Sylwestra, wskazujące na recepcję idei gregoriańskich w ówczesnej Norwegii. Można zakładać zatem, że odwołując się do wydarzeń z dziejów powszechnych Teodoryk nawiązywał do konfliktu pomiędzy królem Sverrirem a norweską hierarchią kościelną, która dążyła do emancypacji spod wpływów świeckich ${ }^{38}$. Jednakże w przywołaniu przez niego w opowieści o chrzcie Olafa kontrowersji związanych z nawróceniem pierwszego chrześcijańskiego cesarza, trudno dostrzec bezpośrednie odniesienia do debaty wokół konstantyńskiej donacji.

\section{Olaf Święty jako nowy Konstantyn?}

Jaką zatem rolę w opowieści o chrzcie Olafa pełni postać Konstantyna Wielkiego? Próbując odpowiedzieć na to pytanie, Sverre Bagge wysunął następującą hipotezę: „,W świetle dzieła Teodoryka jako całości, jego porównanie Olafa do Konstantyna z pewnością nie jest przypadkowe. Olaf jest dla Norwegii tym, kim Konstantyn był dla Cesarstwa Rzymskiego — władcą, który zaprowadził prawdziwą wiarę"39. Hipotezę tę warto zweryfikować, konfrontując ją z innymi przykładami przyrównywania średniowiecznych władców do Konstantyna ${ }^{40}$. Wskazywałem już wyżej na znany przykład Chlodwiga. Jan z Biclar do pierwszego chrześcijańskiego cesarza (i do Marcjona) przyrównywał z kolei króla wizygockiego Rekkareda w związku ze zwołanym przezeń III synodem w Toledo, który

\footnotetext{
37 Mnich Teodoryk, c. 23, s. 47 n.: ,Ego non corporalem sed spiritualem fero gladium; mihi sufficit, si jus suum et patronatus ecclesiæ reddatur, si beato Petro sua restituantur. Tuum est, inquit, carissime fili, decernere, utrum regium nomen in Italia permanere debeat, ex quo Constantinus filius Helenæ ad honorem domini nostri Jesu Christi illud abdicavit et beato Petro ac Romano pontifici in jus perpetuum contradidit".

${ }^{38}$ Szerzej na ten temat - A.O. Johnsen, Om Theodoricus og hans, s. 71 n.; E. Vandvik, Donatio Constantini and, s. 131-137; J.S.Th. Hanssen, Observations on Theodoricus Monachus, s. 167 n.; tenże, Theodoricus Monachus and, s. 102-122; S. Bagge, Theodoricus Monachus - Clerical, s. 119 n., 130 n.; tenże, The Political Thought of The King's Mirror, Odense 1987, s. 113-154, 198-203; P. Foote, Introduction, s. VIII n.; S. Coviaux, Les évêques norvégiens et les idées politiques d'Occident au XIIe siècle, „Médiévales”, 50, 2006, s. 29-46; H. Antonsson, St. Magnús of Orkney. A Scandinavian Martyr-Cult in Context, Leiden-Boston 2007, s. 103-105; B. Bandlien, Hegemonic Memory, CounterMemory, passim.

${ }^{39}$ S. Bagge, Theodoricus Monachus - Clerical, s. 118: „In the light of his work as a whole, his comparison of Óláfr and Constantine is surely no coincidence. Óláfr is to Norway what Constantine was to the Roman Empire, the ruler who introduced the true religion". Również — tamże, s. 121; tenże, Theodoricus Monachus: The Kingdom, s. 77; Th. Foerster, Vergleich und ldentität: Selbst-und Fremddeutung im Norden des hochmittelalterlichen Europa, Berlin 2009, s. 111; V.P. Polách, Historie o starých norských králich. Středověké Norsko a Skandinávie v kronice mnicha Theodorika, České Budějovice 2014, s. 13, 190. Warto zwrócić uwagę, że wzmianka o Konstantynie nie jest - jak uznał Bagge — dygresją, tylko analogią, stanowiącą integralny element opowieści o królu Olafie.

40 Zob. E. Ewig, Das Bild Constantins des Grossen in den ersten Jahrhunderten des abendländischen Mittelalters, „Historisches Jahrbuch”, 75, 1956, s. 133-192; L. Seidel, Constantine ,and' Charlemagne, „Gesta”, 15, 1976, nr 1-2, s. 237-239; P. Magdalino, Introduction, w: New Constantines: The Rhythm of Imperial Renewal in Byzantium, 4th-13th Centuries. Papers from the Twenty-Sixth Spring Symposium of Byzantine Studies, St. Andrews, March 1992, red. P. Magdalino, Aldershot 1994, s. 1-9; T. Wnętrzak, Konstantyn Wielki w oczach Euzebiusza z Cezarei i w badaniach wspótczesnych historyków, w: Euzebiusz z Cezarei, Życie Konstantyna, Kraków 2007, s. 71-81; F. Kolb, Ideat późnoantycznego władcy. Ideologia i autoprezentacja, tłum. A. Gierlińska, Poznań 2008, s. 55-90. O przywoływanej również przez kronikarza matce Konstantyna, cesarzowej Helenie zwięźle - G. Pac, Kobiety w dynastii Piastów. Rola społeczna piastowskich żon i córek do połowy XII wieku — studium porównawcze, Toruń 2013, s. 43 n., 113.
} 
miał tę samą rangę co sobory nicejski i chalcedoński ${ }^{41}$. Grzegorz Wielki przywoływał postać Konstantyna w korespondencji z różnymi władcami - i tak Ethelbertowi z Kentu polecał naśladować jego przykład, by i on i podległe mu ludy mogły dostąpić wiecznego zbawienia ${ }^{42}$. Karol Wielki porównywany był z kolei do Konstantyna przez dwóch autorów — papieża Hadriana i Odilberta z Mediolanu, a to ze względu na zasługi dla Kościoła ${ }^{43}$. Ciekawe zresztą, że Bruno z Kwerfurtu dwukrotnie w swoich pismach wyrażał ubolewanie, że w dzisiejszych czasach nie ma już takich władców, którzy nawracaliby pogan równie gorliwie jak Konstantyn i Karol właśnie. Stawiając ich za wzór Henrykowi II, Kwerfurtczyk uznawał ich działalność za apostolską ${ }^{44}$. Ostatni przykład, z nieco innego kręgu kulturowego, to Włodzimierz Wielki, który nie tylko — podobnie jak jego wielki poprzednik — nawrócił się, ale przed chrztem wykazywał się podobną lubieżnością ${ }^{45}$.

Przyglądając się przytoczonym nieco pobieżnie przykładom, dostrzegamy, że płaszczyzną porównania z pierwszym chrześcijańskim cesarzem jest fakt przyjęcia chrztu przez danego władcę, prowadzona przezeń działalność chrystianizacyjna, a także zasługi dla Kościoła. Czasem Konstantyn zostaje przywołany w dłuższym szeregu wielkich monarchów — dzieje się tak chociażby w liście Odilberta z Mediolanu do Karola Wielkiego. Niekiedy jednak tego typu analogie są bardzo dobitne - Chlodwigowi i Włodzimierzowi przydane zostało wręcz miano „Nowego Konstantyna”. A jak sprawa ma się z Olafem Świętym? Od razu pojawia się drobna wątpliwość, że nie był on — w przeciwieństwie do IV-wiecznego imperatora - pierwszym chrześcijańskim władcą swojego kraju. Nie licząc Haakona Dobrego, poprzedzał go bowiem (o czym doskonale zresztą wiedział Mnich Teodoryk) Olaf Tryggvason, który jako pierwszy zdołał narzucić ,nową wiarę” swojemu ludowi ${ }^{46}$. Z drugiej strony, rola króla-męczennika dla chrystianizacji Norwegii z pewnością nie ulegała w średniowieczu wątpliwości.

Przede wszystkim jednak, płaszczyzną porównania Olafa z Konstantynem nie jest sam fakt przyjęcia chrztu. Przypomnijmy interesujące nas zdanie: „Nec mirum de Olavo hoc contigisse in illa terra, ubi nullus antiquitatum unquam scriptor fuerit, cum idem scribat beatus Hieronymus de Constantino Magno filio Constantii et Helenæ, quod quidam dicant eum Bithyniæ baptizatum fuisse in ultima senectute, alii Constantinopoli, quidam Romæ a beato Sylvestro papa, et adhuc sub judice lis est quis verius scripserit". Jak widać, z Olafem hoc contigisse, że funkcjonują różne opinie na temat jego chrztu, zaś idem o Konstantynie pisał Hieronim. A zatem, król norweski jest o tyle podobny do rzymskiego

\footnotetext{
${ }^{41}$ Iohannis abbatis Biclarensis Chronica a. DLXVII-DXC, wyd. Th. Mommsen, MGH AA, t. 11, Berolini 1894, s. 219. Szeroko na temat III synodu toledańskiego (589), zob. B. Dumézil, Les racines chrétiennes de l'Europe, s. 279 n.

${ }^{42}$ Gregorii I Papae Registrum Epistolarum, wyd. P. Ewald, M.L. Hartmann, MGH Ep., t. 2, Berolini 1899, lib. XI, c. 37, s. 309. Zob. B. Dumézil, Les racines chrétiennes de l'Europe, s. 157 n., 162, 304 n.

${ }^{43}$ Codex Carolinus, wyd. W. Grundlach, MGH Ep., t. 3, Berolini 1892, nr 60, s. 587; Odilberti ad Karolum M. Respondium 809-812, wyd. A. Boretivs, MGH Capitularia, t. 1, Hannoverae 1883, s. 247. Por. A. Gieysztor, Wtadza Karola Wielkiego w opinii współczesnej, Warszawa 1938, s. 20, 46 n.; E. Ewig, Das Bild Constantins, s. 170 n.; L. Seidel, Constantine ,and' Charlemagne, passim.; K. Hauck, Karl als neuer Konstantin 777. Die archäologischen Entdeckungen in Paderborn in historischen Sicht, „Frühmittelalterliche Studien”, 20, 1986, s. 513-540; R. Michałowski, Prüm i Urbs Caroli. Monarsze fundacje na tle kultury politycznej wczesnych czasów karolińskich, w: Fundacje i fundatorzy w średniowieczu i epoce nowożytnej, red. E. Opaliński, T. Wiślicz, Warszawa 2000, s. 20-32.

${ }^{44}$ Epistola Brunonis ad Henricum regem, wyd. J. Karwasińska, MPH n.s., t. 4, z. 3, Warszawa 1973, s. 104; Bruno z Kwerfurtu, Sancti Adalberti pragensis episcopi et martyris Vita Altera, wyd. J. Karwasińska, MPH n.s., t. 4, z. 2, Warszawa 1969, c. 10, s. 10. Szerzej - R. Michałowski, Zjazd Gnieźnieński. Religijne przesłanki powstania Arcybiskupstwa Gnieźnieńskiego, Wrocław 2005, s. 308, 367 n.; M. Sas, Działalność św. Brunona z Kwerfurtu, „Teka Historyka”, 38, 2009, s. 66-73.

45 Повєсть временныхъ лєт, s.a. 6523 (AD 1015): „се єсть новы Костантинъ великаго Рима иже крсти все люди своа самъ и тако сии створиша", tekst latopisu dostępny na stronie: <http://litopys.org.ua> [dostęp: 11.03.2014]. Por. G. Podskalsky, Chrześcijaństwo i literatura teologiczna na Rusi Kijowskiej (988-1237), tłum. J. Zychowicz, Kraków 2000, wg indeksu: Konstantyn.

${ }^{46} \mathrm{O}$ dziejopisarskich wizerunkach tych władców, zob. S. Bagge, A Hero between Paganism and Christianity. Håkon the Good in Memory and History, w: Poetik und Gedächtnis. Festschrift für Heiko Uecker zum 65. Geburtstag, Bonn 2004, s. 185-210; tenże, The Making of a Missionary King, passim; Ó. Einarsdóttir, Olaf Tryggvason - Rex Norwegiae 994-999. Christian Ethics versus Teutonic Heroism, w: Scandinavia and Christian Europe in the Middle Ages. Papers of the 12th International saga Conference, red. R. Simek, J. Meurer, Bonn 2003, s. 413-420.
} 
cesarza, że nie wiadomo, kiedy nawrócił się on na chrześcijaństwo, a nie dlatego, że w ogóle się na nie nawrócił. Wydaje się oczywiście, że analogia z taką starożytną postacią nie może być przypadkowa; a jednak, Teodoryk, relacjonując dalsze życie Olafa, nie wraca do niej, ani jej w żaden sposb nie rozwija.

Aby powyższe spostrzeżenia doprecyzować, przyjrzyjmy się kontekstowi narracyjnemu, $\mathrm{w}$ jakim pojawia się wzmianka o niepewnościach związanych z chrztem rzymskiego cesarza.

\section{Czy Norwegowie mają swoją historię?}

Zdanie, w którym mowa o wątpliwościach związanych z chrztem Olafa i Konstantyna wywołało w literaturze skandynawistycznej dyskusję, sprawiającą wrażenie oderwanej od kontekstu całej opowieści. Kolejni badacze rozważali znaczenie dwóch powiązanych ze sobą zwrotów, a mianowicie antiquitatum scriptor i illa terra. Zacznijmy od tej drugiej kwestii. Otóż illa terra to kraj, w którym brak tradycji historiograficznych, które pozwalałaby w sposób jednoznaczny rozstrzygnąć, gdzie i kiedy został ochrzczony św. Olaf. Wydaje się zatem naturalne, że krajem tym jest Norwegia, gdzie Olaf żył i panował - a także, gdzie żył i pisał Mnich Teodoryk ${ }^{47}$.

Ist das zutreffend? — pytał jednak Siegfried Beyschlag, i odpowiedział, że illa terra oznacza nie Norwegię, tylko Islandię ${ }^{48}$. Podstawą takiego stanowiska były dwa założenia. Po pierwsze, autor klasycznej pracy o sagach królewskich, przyjął poprzednie zdanie opowieści w formie podanej przez Gustava Storma: „Sed sive Rothomagi sive in Anglia baptizatus fuerit, tunc constat eum fuisse provectioris ætatis, quam illi dicunt, quibus maxime in hujusmodi credendum est”. Jak widać — zdaniem Storma - fraza o męczeństwie Olafa w tym zdaniu miałaby być interpolacją ${ }^{49}$, frazę zaś doty-

47 Tak uważali m.in. G. Storm, Indledning, s. X; R. Meissner, Die Strengleikar. Ein Beitrag zur Geschichte der altnordischen Prosaliteratur, Halle a.S. 1902, s. 32; B. Aðalbjarnarson, Om de norske kongers sagaer, s. 6; A.O. Johnsen, Om Theodoricus og hans, s. 15; Th.M. Andersson, Ari's ,konunga cevi” and the Earliest Accounts of Hákon Jarl's Death, w: Bibliotheca Arnamagnceana, t. 33 (Opuscula, 6), København 1979, s. 11, przyp. 4; S. Bagge, The Making of a Missionary King, s. 490, zwłaszcza przyp. 66.

${ }^{48}$ S. Beyschlag, Konungasögur. Untersuchungen, s. 126 n. Podobnie - S. Ellehøj, Studier over den celdste, s. 178; J. de Vries, Altnordische Literaturgeschichte, t. 2, Berlin-New York 1999, s. 249, przyp. 46. Nie miałem dostępu do: J. Kristjánson, Um Fóstbrœðrasögu, Reykjavík 1972, s. 146.

${ }^{49}$ Wedle Teodoryka, niezależnie od tego, gdzie i kiedy Olaf przyjął chrzest, nie ma wątpliwości co do tego, że był już dojrzały w momencie, w którym nastąpiła jego męczeńska śmierć. Taka konstrukcja wprowadziła Storma w konfuzję: jaki związek logiczny miałby zachodzić bowiem pomiędzy niemożnością rozstrzygnięcia, gdzie ochrzcił się Olaf, a tym kiedy został on męczennikiem? Dlatego wydawca uznał znajdującą we wszystkich rękopisach frazę quando martyrio coronatus est za interpolację (G. Storm, w: Mnich Teodoryk, s. 23, przyp. 11; tenże, Om Haandskrifterne af Thjodrek Munk, Christiania 1875, s. 4). Usunięcie jej z tekstu (albo zastąpienie przez quando baptizaretur) byłoby równoznaczne z negacją opinii głoszonej przez „niektórych” (quosdam), jakoby król został ochrzczony przez Tryggvasona jako trzyletni chłopiec, a potwierdzeniem tego, że stało się to sive Rothomagi sive in Anglia, i miało to miejsce, kiedy Olaf był już provectioris cetatis. Pozbawione „wtrętu” o męczeńskiej śmierci zdanie wydaje się klarowną próbą częściowego przynajmniej rozstrzygnięcia wątpliwości co do okoliczności nawrócenia Olafa. Z krytyką Storma wystąpiła Gudrun Lange, która dowodziła, że wzmianka o męczeństwie jest tu na miejscu, skoro już wcześniej, w tym samym rozdziale, Olaf przedstawiony został słowami qui postea devotus Christi martyr factus est (G. Lange, Die Anfänge, s. 101. Podobnie — D. McDougall, I. McDougall, w: Theodoricus Monachus, An Account, s. 73, przyp. 104. Inaczej — E. Kraggerud, Theodoricus Scrutinized, s. 123 n.; J. Jochens, rec.: Theodoricus Monachus, An Account, ,Journal of English and Germanic Philology”, 100, 2001, nr 1, s. 83; S. Bagge, The Making of a Missionary King, s. 489, przyp. 63). W obydwu miejscach mamy do czynienia z futurospekcją, przejściem od chrztu do męczeńskiej śmierci. Dodajmy, że podobnego zwrotu w odniesieniu do Olafa używa Teodoryk raz jeszcze — kiedy młody władca powrócił do Norwegii za panowania jarla Hakona Eirikssona, został przypomniany czytelnikowi słowami postea martyr Christi futurus (Mnich Teodoryk, c. 15, s. 25). Dlaczego i to nie miałaby być interpolacja? Obserwacja dokonana przez Lange stanowi zatem istotną przesłankę. Hipoteza dotycząca interpolacji nie przekonuje także z tego powodu, że nie mogła zostać poparta argumentami paleograficznymi, ani filologicznymi; wszak nasza wiedza o tradycji rękopiśmiennej Historii jest pełna luk, nie dysponujemy również średniowiecznymi tekstami, których autorzy recypowaliby ten konkretny fragment dzieła. Storm i badacze, którzy przyznali mu w omawianej sprawie rację, mogli odwołać się jedynie do własnego, a więc nowoczesnego, wyczucia, jak powinna być skonstruowana logiczna wypowiedź. (Doprowadzając hipotezę Storma ad absurdum, można by stwierdzić, że tekst Historia de antiquitate w całości stanowi XVII-wieczny apokryf). Trzeba 
czącą wiarygodnych źródeł otwierałby spójnik quam, a nie quomodo ${ }^{50}$. Po drugie, Beyschlag uznał, że wspomniani tamże ,illi [...] quibus maxime in hujus modi credendum est” - to Islandczycy, i to oni właśnie mieliby stanowić źródło podanej w wątpliwość (przez użycie zwrotu provectioris cetatis) opinii mówiącej o przyjęciu przez władcę chrztu w wieku trzech lat z rąk jego poprzednika $\mathrm{i}$ imiennika. Przeto, konkluduje Beyschlag, kronikarz neguje ją dlatego, że to właśnie na Islandii „nullus antiquitatum unquam scriptor fuerit".

Tymczasem, choć Teodoryk po dwakroć powołuje się w swoim dziele na islandzkie antiqua carmina, a ich wpływu na omawianą opowieść całkowicie wykluczyć nie można, to brakuje jakiejkolwiek jednoznacznej wskazówki pozwalającej zidentyfikować tych, którzy lokowali chrzest Olafa w Upplandzie $\mathrm{z}$ islandzkimi skaldami. Niewątpliwe zainteresowanie twórców poematów osobą władcymęczennika nie ma bezpośredniego związku z sensami literalnie wpisanymi w treść analizowanego przekazu $^{51}$. Jeśli bowiem przyjąć, że pod illa terra kryje się Islandia, wówczas cała opowieść straci sens, a ten opiera się na pewnej symetrii: Olaf jest podobny do Konstantyna nie dlatego, że jedna z opinii na temat okoliczności jego chrztu jest fałszywa, tylko dlatego, że na ten temat krążą trzy konkurencyjne opinie.

Zastrzeżenia wzbudziło również użycie w analizowanym zdaniu zaimka illa zamiast $h a c^{52}$. I faktycznie, kronikarz frazą in hac terra posługuje się trzykrotnie w prologu do swojego dzieła, mówiąc o tym, że przed objęciem tronu przez Haralda Pięknowłosego nie było — w Norwegii właśnie dynastii królewskiej, byli natomiast mężowie prawi, sławni i wojowniczy, którzy wyprawiali się do Galii, o czym przeczytać można u testes idonei - czyli w kronikach Hugona od św. Wiktora i Siegeberta z Gembloux. Pamięć o nich, jak twierdzi Teodoryk, przepadła jednak z powodu braku źródeł pisanych $^{53}$. Nie jestem jednak przekonany co do tego, czy Teodoryk powinien był koniecznie użyć zaimka hac w miejsce bardziej naturalnego dla łaciny średniowiecznej illa. Przede wszystkim zaś co Olaf Święty miałby mieć wspólnego z Islandią, by brak tamtejszych źródeł pisanych wiązał się z niemożnością ustalenia okoliczności chrztu tegoż władcy?!

Dla porządku dodajmy, że z jeszcze inną hipotezą wystąpiła Gudrun Lange. Wedle Lange, illa terra oznacza te kraje, w których miałby się ochrzcić Olaf — czyli Uppland, Anglię i Normandię. Ponieważ jednak illa terra jest w singularis, frazę tę należy (zdaniem Lange) odczytać jako auf dieser Erde, ewentualnie jako auf dieser Welt ${ }^{54}$. Nie jest jednak dla mnie jasne, w jaki sposób tak zinterpreto-

zatem założyć, że fraza o ukoronowaniu Olafa męczeństwem w zdaniu dotyczącym okoliczności jego chrztu znajdowała się już w pierwotnej wersji kroniki. Każe to postawić pytanie o związek chrztu i męczeństwa w myśli średniowiecznej.

${ }^{50}$ W rękopisach, z których korzystał Storm (A, S) frazę dotyczącą wiarygodnych źródeł, które podają, że Olaf był provectioris cetatis, otwiera spójnik quam. A zatem: Olaf „był starszy (przyjmując chrzest) niż twierdzą ci, którzy są w tej sprawie wiarygodni" (Mnich Teodoryk, s. 23; G. Storm, w: tamże, s. 22 n., przyp. 11). Taki odczyt wydaje się jednak pozbawiony sensu: jak bowiem można twierdzić, że ktoś jest w danej sprawie wiarygodny, a zarazem korygować podawaną przez niego informację? Jak jednak zwróciła uwagę G. Lange, nie wszystkie rękopisy mają w tym miejscu spójnik quam. Nieznane Stormowi kopie M i L, podają odpowiednio cum i quomodo, editio princpeps natomiast — quemadmodum (Ms. lat. fol. 356, k. 17 v.; Commentarius Prior Historicus, De Regibus Vetustis Norvagicis, Ducentorum circiter annorum res gestas complectens à Theodorico Monacho Nidrosiensi, wyd. B.C. Kirchmann, Commentarii Historici Duo hactenus inediti, Amstelodami 1684, s. 22; G. Lange, Die Anfänge, s. 100 n.; D. McDougall, I. McDougall, w: Theodoricus Monachus, An Account, s. 72 n., przyp. 104). Szczególnie ta druga lekcja (jako pochodząca od odkrywcy kroniki, Johanna Kirchmanna) wzbudza zaufanie, stąd przyjmuję ją jako prawidłową. Wszystkie trzy zaś rozwiązują sztuczny konflikt pomiędzy podaną informacją a oceną wiarygodności źródła, z którego została zaczerpnięta.

${ }^{51}$ Podobnie - S. Bagge, The Making of a Missionary King, s. 490.

52 Tamże. Sverre Bagge wyraził taką wątpliwość, rozważając roboczo hipotezę Beyschlaga.

${ }^{53}$ Mnich Teodoryk, prolog, s. 3-4. Statusem historycznym owych wikingów nie zajmowano się jak dotąd. Sama opowieść przyciągała uwagę badaczy ze względu na wymienione w niej imiona trzech autorów. Oprócz Hugona i Siegeberta jest to Boecjusz - zob. E. Karlsen, K. Vatsend, On Theodoricus Monachus' Use of Late Classical Authors, „Collegium Medievale”, 16, 2003, s. 255-259; E. Kraggerud, Boëthius and the Preface of Theodoricus' „Historia” — „opinio” versus „,oblivio” once again, „Collegium Medievale”, 18 (2005), s. 144-147.

${ }^{54}$ G. Lange, Die Anfänge, s. 102 n. Por. D. McDougall, I. McDougall, w: Theodoricus Monachus, An Account, s. 73, przyp. 105. 
wany zwrot miałby funkcjonować w kontekście całości zdania ${ }^{55}$. Reasumując: in illa terra znaczy tyle co „w Norwegii”; brak wiedzy o dacie i miejscu chrztu Olafa wynika z tego, że przed Teodorykiem nie było w Norwegii żadnego kronikarza, którego świadectwo pozwalałoby tę kwestię rozstrzygnąć. Wszelkie inne sposoby odczytania omawianego zdania należy traktować jako „lekturę alternatywną”.

Spróbujmy teraz odpowiedzieć na pytanie, kto kryje się pod określeniem antiquitatum scriptor. Z kontekstu wynika - i co do tego nie ma wątpliwości - że chodzi tu o autora, którego można by porównać ze św. Hieronimem. Nie jest jednak jasne, czy zwrot ten należy przetłumaczyć jako „kronikarz dziejów starożytnych” czy — jak chcieliby Lange i Bagge — jako „kronikarz starożytny”. Zdaniem obydwojga tych badaczy, antiquitatum scriptor miałby być naocznym świadkiem wydarzeń $^{56}$ — kimś takim z pewnością nie czuł się sam Teodoryk, który urwał swoją opowieść na pół wieku przed momentem rozpoczęcia swojej kroniki, deklarując przy tym, że spisuje dzieje non visa, sed audita $^{57}$. W tradycji średniowiecznego dziejopisarstwa dominowało przekonanie o wyższości wiedzy uzyskanej naocznie nad wiedzą zasłyszaną. W rezultacie, opowieść o dziejach, których nie było się naocznym świadkiem, musiała zostać oparta na świadectwach osób o niekwestionowanym autorytecie rozumianym w kategoriach moralnych ${ }^{58}$.

Antiquitatum scriptor to filologicznie jednak „kronikarz starożytności”, czy — bardziej zgrabnie pod względem językowym — „kronikarz dziejów starożytnych”. Rozpatrzmy zatem, co chciał zasygnalizować Teodoryk, mówiąc, że dotąd nie było kogoś takiego w Norwegii. Odwołajmy się w tym celu do innych fragmentów jego dzieła i zobaczmy, jak sam siebie postrzegał jako historyka ${ }^{59}$. Już w prologu oznajmia on, że zdecydował się spisać kronikę, ,,ponieważ niemal żaden lud nie jest na tyle surowy i nieokrzesany, by w jakiś sposób pomników swoich przodków potomności nie przekazał" Ubolewa on również, że początkowe dzieje Norwegii zostały okryte mgłą zapomnienia z powodu braku źródeł pisanych — ,trudno jest bowiem w tym dotrzeć do pewnej prawdy, zwłaszcza gdy nie ma się wsparcia w żadnym autorytecie dziejopisarzy", tzn. gdy jedyne źródło stanowi przekaz oralny ${ }^{61}$. W epilogu wreszcie (symetrycznym względem prologu) oznajmia Teodoryk, iż podjął się swojego zadania wyłącznie dlatego, że nie ma nikogo innego, kto by mógł je przedsięwziąć. Wszakże — mówi kronikarz - lepszy w tej sytuacji jestem ja aniżeli nikt w ogóle ${ }^{62}$.

Płynie stąd wniosek, że Teodoryk uważał się za pierwszego kronikarza w swojej ojczyźnie, co niosło ze sobą ważkie implikacje w sferze zarówno epistemologicznej, jak i tożsamościowej ${ }^{63}$. Pionierska rola, jaką w swoim przekonaniu do odegrania miał dziejopis, wiązała się ze znacznymi nie-

\footnotetext{
${ }_{55}$ Podobnie - S. Bagge, The Making of a Missionary King, s. 490, przyp. 66.

${ }^{56}$ G. Lange, Die Anfänge, s. 102; S. Bagge, The Making of a Missionary King, s. 489 n. Por. D. McDougall, I. McDougall, w: Theodoricus Monachus, An Account, s. 73, przyp. 105.

${ }_{57}$ Mnich Teodoryk, prolog, s. 4; c. 34, s. 68. Por. D. McDougall, I. McDougall, w: Theodoricus Monachus, An Account, s. 56, przyp. 11.

${ }^{58}$ Zob. K. Pomian, Przeszłość jako przedmiot, s. 46-107; M. Schulz, Die Lehre von der historischen, s. 17-20, 28-31. Zwróćmy jednak uwagę, że Hieronim — abstrahując już od tego, co mógł na temat jego życia wiedzieć Teodoryk — urodził się już po śmierci Konstantyna, nie mógł być zatem naocznym świadkiem cesarskiego nawrócenia.

${ }_{59}$ Por. B. Lincoln, Between History and Myth: Stories of Harald Fairhair and the Founding of the State, Chicago-London 2014, s. 109 n.; J. Banaszkiewicz, Master Vincent and His Way to Revive and Present the Oldest History of the Lechites-Poles, w druku (dziękuję Panu Profesorowi za udostępnienie mi tego artykułu przed publikacją).

${ }^{60}$ Mnich Teodoryk, prolog, s. 3: „quia pæne nulla natio est tam rudis et inculta, quæ non aliqua monumenta suorum antecessorum ad posteros transmitterit". Na temat prologu do kroniki, por. J.S.Th. Hanssen, Theodoricus Monachus and, s. 7178; S. Tómasson, Formálar íslenskra sagnaritara á miðöldum. Rannsókn bókmenntahefðar, Reykjavík 1988, wg indeksu: „Theodricus monachus”; S. Bagge, Theodoricus Monachus - Clerical, s. 115-117.

${ }_{61}$ Mnich Teodoryk, prolog, s. 3-4; c. 1, s. 6: „valde difficile est in hisce ad liquidum veritatem comprehendere, maxime ubi nulla opitulatur scriptorum autoritas".

62 Tamże, c. 34, s. 68: „Et sciat pro certo me istarum rerum relatorem alium potius voluisse quam me; quod quia hactenus non contigit, me malui quam neminem”. Por. E. Skard, Målet i „Historia Norwegiae”, Oslo 1930, s. 75; G. Simon, Untersuchungen zur Topik der Widmungsbriefe mittelalterlicher Geschichtsschreiber bis zum Ende des 12. Jahrhunderts, cz. 1, „Archiv für Diplomatik”, 4, 1959, s. 79 n.

${ }^{63}$ Por. tamże, s. 77 n.
} 
dogodnościami natury warsztatowej. Brak źródeł pisanych utrudniał bowiem zadanie polegające na wiarygodnym zrekonstruowaniu norweskiej przeszłości. Na podobną przeszkodę natrafił Teodoryk także przy próbie odpowiedzi na pytanie, gdzie i kiedy ochrzcił się św. Olaf. Okoliczności konwersji tego władcy były dlatego niejasne, że nie było rodzimej tradycji historiograficznej, która mogłaby tę sprawę jednoznacznie rozstrzygnąć. Nawet świadectwo pisane, jakim był przekaz Gestów Wilhelma z Jumièges, nie mogło niczego rozjaśnić, a jedynie — w konfrontacji z konkurencyjnymi przekazami — wprowadzało dodatkowe zamieszanie.

Ale skoro nawet w wielkiej historii powszechnej, w historii Cesarstwa Rzymskiego, zdarzają się takie sytuacje, że na temat jakiegoś istotnego wydarzenia krążą różne, wzajemnie się wykluczające opinie, to dzieje Norwegii, w której „nigdy nie było żadnego kronikarza dziejów starożytnych”, nie wypadają na jej tle aż tak źle, jak mogłoby się wydawać. Innymi słowy, analogia konstantyńska służy zniwelowaniu dyskomfortu, jaki w oczach Teodoryka stanowiły niejasności dotyczące miejsca i czasu chrztu Olafa. Dyskomfortu związanego z przekonaniem, że udokumentowana historia jest oznaką ludu cywilizowanego, a jej brak stanowi znamię barbarzyństwa ${ }^{64}$. W podobny sposób jak Norweg historyczne niejasności wygrywał piszący w XIV w. kronikarz Jakub de Guisia. Przekonywał on, że początki Hainault uległy zapomnieniu w stopniu nie mniejszym niż dawne dzieje szczególnie wywyższonych przez Boga Izraelitów. Czego zatem można spodziewać się po historii ludu, który jeszcze stosunkowo niedawno czcił bałwany ${ }^{65}$ ?

\section{In illa terra, ubi nullus antiquitatum unquam scriptor fuerit. History as a Component of the Identity of a Civilised People (Upon the Example of an Account by Theodoricus Monachus of the Circumstances of the Baptism of St. Olaf)}

The article presents the circumstances of the baptism of St. Olaf recounted by Theodoricus Monachus, a Norwegian chronicler from the end of the twelfth century. Theodoricus noted that the time and place of the ruler's christening remained unknown. This is not surprising since, he added, up to then Norway did not have a chronicle of ancient times, and even St. Jerome was uninformed about data concerning the christening of Constantine the Great. The presented analysis pertains to sources used by Theodoricus to learn about the emperor's baptism and traces of a twelfth-century discussion about the donation made by him and Constantinian ideology. Finally, the author inquired into the meaning of a comparison of the two rulers in view of the fact that the chronicler did not envisage the Norwegian king as a „New Constantine” but was concerned with demonstrating that the until recently barbarian Norwegians, who did not have at their disposal a historiographic tradition of their own, did not differ much from the level delineated by ancient civilisation. After all, even the Romans were uncertain where the first Christian emperor had been baptised.

Kontakt do autora: rr.rutkowski@wp.pl

\footnotetext{
${ }^{64}$ Por. S. Bagge, Theodoricus Monachus - Clerical, s. 121-122. Nie był to pogląd w średniowieczu odosobniony. Gall Anonim w następujący sposób przestrzegał bowiem swoich krytyków: „Quodsi reges Polonos vel duces fastis indignes annalibus iudicatis, regnum Polonie procul dubio quibuslibet incultis barbarorum nationibus addicatis" (Galli Anonymi Cronicae et gesta ducum sive principum Polonorum, wyd. K. Maleczyński, MPH n.s., t. 2, Kraków 1952, lib. III, epist., s. 121). Por. G. Simon, Untersuchungen zur Topik der Widmungsbriefe, cz. 1, s. 79, 82; T. Michałowska, Galla Anonima wiersz o twórczości pisarskiej (glosy do tekstu), w: Łacińska poezja w dawnej Polsce, red. T. Michałowska, Warszawa 1995, s. 7-24; M. Cetwiński, Między historią a poezją. Walory edukacyjne śląskich kronik, w: tenże, Metamorfozy śląskie. Studia źródłoznawcze i historiograficzne, Częstochowa 2002, s. 48 n.; J. Banaszkiewicz, Gall jako historyk poważny, czyli dlaczego dzieje i Bolestawa Chrobrego, i Bolesława Krzywoustego sa prawdziwe i niegroteskowe, w: tenże, Takie sobie średniowieczne bajeczki, Kraków 2012, s. 563-585; W. Wojtowicz, Tarda loquendi facultas — tożsamość tzw. Galla Anonima w kontekście listów i epilogów „Gestów”, „Pamiętnik Literacki”, 104, 2013, z. 3, s. 5-38.

${ }^{65}$ Iacobi de Guisia Annales historiae illustrium principum Hanoniae, wyd. E. Sackur, MGH SS, t. 30, z. 1, Hannoverae 1896, c. 9, s. 85. Por. J. Banaszkiewicz, ,,Kronika Dzierzwy”. XIV-wieczne kompendium historii ojczystej, Wrocław 1979, s. 32.
} 